\title{
Water in Las Vegas: coping with scarcity, financial and cultural constraints
}

\author{
Frederic Lasserre
}

\begin{abstract}
Background: Las Vegas has often been described as offering the paradox of wasting large amounts of water for the tourism industry, whereas it is located in an arid desert area. However, a closer examination shows that it is residential demand that is responsible for most of water use.

Method: This paper will rely on the analysis and comparison of the main water policy elements in several Western cities, with a special focus on Las Vegas.

Results: The city authorities embarked, in the late 1950s, in policies aimed at reducing a very large residential water demand. If the authorities have been successful, efficiency gains can certainly be achieved as per capita use remains high in the Las Vegas area, and tariffs low.

Conclusion: Political, sociological, legal and technical constraints weigh in to provide for a difficult equation to solve for water authorities. These difficulties might explain why the lure of massive water diversions is looming high again.
\end{abstract}

Keywords: Water; Water use; Watershed; Las Vegas; Water authority; Outdoor water use; Price; Tariff; Incentives; Diversions

Las Vegas sits in the Mojave desert: the city benefits from $10 \mathrm{~cm}$ of rain each year (NOAA - National Oceanic and Atmospheric Administration 2015), as underlined by Patricia Mulroy (Mulroy, 2000), who acted as head of the Southern Nevada Water Authority (SNWA) between 1991 and 2014. The booming city displayed a fast population expansion (Table 1) and economic growth largely based on tourism and gambling. Images of lush use of water for fountains by luxury hotels like the Caesar's Palace, Bellagio, Mirage, Venetian, Treasure Island, have contributed to depict Las Vegas as a wasteful city regarding water use.

Although these images are true, they must not be misinterpreted. Las Vegas's use of water may be large, but it is largely due to domestic water use, not so much because of hotels and casinos. Las Vegas's very existence in a desert region thus underlines several paradoxes: the water authorities managed to fulfill the city's demand despite the very high per capita use; contrary to the widely accepted image, the city's large water use rests

Correspondence: frederic.lasserre@ggr.ulaval.ca

Laval University, Quebec City, QC, Canada largely on residential use and not so much on economic activity.

Las Vegas managed to cope with water scarcity all the while enabling hotels and casinos to perpetuate the illusion of abundance. However, this abundance is an illusion and the SNWA, the water authority that services Las Vegas, is struggling to cope with a growing demand. A bold policy of curbing outdoor water use was implemented and gave interesting results in the past two decades, but it seems the still expanding demand in the context of a severe drought plaguing the West since 2008. A closer examination at the water policy implemented by the SNWA and the Las Vegas Valley Water District (LVVWD) underlines discrepancies with other Western cities, notably on pricing policies and on efforts put on indoor water use control.

To what extent is Las Vegas water policy exemplary in its desert context? What are the main elements of Las Vegas's water policy, and what differences with other Western cities can be discerned? This paper will rely on the analysis and comparison of the main water policy 
Table 1 Population of selected Western US cities - Metropolitan area. In thousands

\begin{tabular}{lllllll}
\hline & 1970 & 1980 & 1990 & 2000 & 2010 & 2013 \\
\hline Las Vegas & 277 & 463 & 756 & 1380 & 1950 & 2030 \\
Tucson & 352 & 531 & 667 & 844 & 1078 & 997 \\
Phoenix & & 1509 & 2240 & 3252 & 4193 & 4380 \\
Albuquerque & & 485 & 586 & 730 & 887 & 915 \\
\hline
\end{tabular}

Source: US Census Bureau

elements in several Western cities, with a special focus on Las Vegas.

\section{Coping with a growing population with high per capita use}

Like several Western cities in the United States, Las Vegas undertook a fast population growth since the 1970s, resulting in a fast increase in water demand, both for economic and domestic water uses. The Clark County's population was 277000 in 1970, 463000 in 1980 and 756 000 in 1990. In 2000, the population of the Las Vegas Metropolitan Area (coextensive with Clark County since 2003) was 1,38 million; 1,9 million in 2009, and 2,03 million in 2013. Similar population growths were witnessed in most Western cities, Los Angeles, San Diego, Tucson, Phoenix, Santa Fe, Albuquerque, placing a serious stress on local water authorities so as to keep pace with a fast expanding demand (Lasserre 2003, 2006), although in the last past years growth seems to slow down. This urban growth, coupled with strong agricultural water demand, is all the more worrying as, despite a slowing down in recent years, the level of withdrawals from the Colorado basin is clearly reaching unsustainable levels, water use regularly exceeding water supply since about 2002 (Bureau of Reclamation 2012).

True, urban demand, whether it is for residential uses, institutions or for economic agents (services like hotels or retail; industry) accounts for a fraction of water withdrawals in the West: public supply accounted for $13 \%$ of water withdrawals in the United States in 2005 and 12,8\% (estimated) in 2010 (USGS, United States Geological Survey 2014a). In California, public supply accounted for $16,6 \%$ of water withdrawals in 2010, and irrigation $60,7 \%$ (USGS and United States Geological Survey 2014b). In Arizona, agriculture accounted for about $75 \%$ of water withdrawals in 2006 and urban use $20 \%$ (Pitzer et al. 2007). However, the allocation system in the Western United States is largely based on the prior appropriation principle and not the riparian allocation system as in the Eastern United States or most of the world (Thompson 1999; Lasserre 2006; Johnson 2009; Lasserre 2012), which means cities must make do with the limited supply they have acquired rights on in the past. The equation, for municipal water planners, boils down to finding ways to either expand the volume of water available through diversions and/or water rights acquisition, or to manage demand so as to limit its expansion within the water budget. Expanding supply has long been the privileged option, with large supplies available in groundwater-Las Vegas was developed on a sedimentary basin where the aquifer lied few meters below the surface, at times gushing out when a well was drilled-or through the diversion of rivers (like the Los Angeles Aqueduct (1913, extended to Mono Lake in 1940), the Hetch Hetchy Canal (to San Francisco, 1934), the Colorado River Aqueduct (to Los Angeles and San Diego, 1941) or the San Juan Chama (1970) that brings additional water to the Albuquerque area notably (Lasserre 2005). However, the fast depletion of groundwater, the high cost of building large-scale diversions and the limited water not already acquired under the appropriation system encouraged cities to develop conservation policies beginning in the 1950s.

\section{Pushed by active policies, per capita water use is declining}

Recently, per capita use in the Las Vegas area dropped from 350 gallons per day per capita (gpcd) (1 223,6 1 per day per capita) in 1989 to 322 gpcd in 1997, 264 gpcd in 2006 and 212 gpcd in 2013 (Cooley et al. 2007; Thompson J 2014a, 2014b; SNWA 2014b; SNWA 2015). Between 2002 and 2012, the metropolitan area grew by more than 400000 people, added 25000 hotel rooms, yet total annual water use dropped by 110 million $\mathrm{m}^{3}$ (Thompson 2014a), in part because of the 2008 economic crisis (Velotta 2011), but also largely because of water conservation efforts. The city has achieved a remarkable control of water demand. The reduction in water use per capita is not a recent phenomenon, it began in the 1950s with metering and ordinances when overdrafting of the aquifer began to deplete the resource, forcing the city to consider tapping the Colorado River from conveniently closer Lake Mead, $30 \mathrm{~km}$ away, and curbing the incredibly high residential water use that reached 597 gpcd in 1945 (Morris et al. 1997). The tourism industry was not responsible for this high water use: the El Rancho Vegas Hotel opened in April 1941 with 110 rooms, and quickly expanded as new resorts opened up in the area; however, the tourism industry was not as developed as it is now and since there was little industry in the area at the time, this high use was mostly due to high domestic water demand, just as now.

Indeed, a recurrent myth about Las Vegas is that fountains, golf courses, casinos and hotels are responsible for a lot of waste. This image is certainly strengthened by the images of these huge fountains displayed by the 
major hotels on the Strip. However, it is an illusion. Hotel resorts were responsible for only $7,6 \%$ of water use in Southern Nevada in 2013, and golf courses 6,4 \% (SNWA 2014a). Las Vegas's tourism industry is very water-efficient. Fake grass, recycled water for golf courses or fountains, reduced-flow fixtures, the industry abided by tight regulations and made a real effort to curb water use (Lasserre 2006; Thompson 2014a, 2014b). Single-family residential demand accounted for $44,8 \%$ and multi-family residential demand for 15,8 \%-residents overall are responsible for $60,6 \%$ of the water used in Las Vegas in 2013, especially residents in single-family housing, a residential use up from 58 \% in 2004 (Western Resource Advocates 2006).

Las Vegas is not the only city in the USA that managed to achieve a better control of water use, whether on a per capita or in absolute terms. Figures released from the Los Angeles Department of Water and Power showed that it supplied less water in February 2010 than any time in the last three decades (Walton 2010a).

In Phoenix, total urban use went from 276,3 gpcd in 1981, to 242 in 1994 and 208 gpcd in 2005, with important inter-annual variations reflecting meteorological variability, an element all the more important as outdoor use was estimated at $74 \%$ of total water demand in 1999 (Balling and Gober 2007).

In El Paso (TX), water use was brought from 172 gpcd in 1992 to 159 gpcd in 2000, then 130 gpcd in 2013 (Earl and Czerniak 1996; EPWU 2014).

In Santa Fe, per capita use had dropped $42 \%$ in 2010 (100 gpcd) since 1995 (160 gpcd) and total use was down nearly $30 \%$, while Phoenix used the same amount of water in 2010 as it did 10 years ago despite adding roughly 400000 residents. In 2013 it stood at 101 gpcd (City of Santa Fe 2014).

In Albuquerque, water demand went from 250 gpcd in 1994 to 205 in 2001 then 173 in 2005 and 160 in 2009 (Western Resource Advocates 2006; Hurd B 2010).

In Tucson, total urban use stood at 177 gpcd in 2004 (City of Tucson Water Department 2004); then at 127,4 gpcd in 2013, of which residential demand was $69 \%$ (City of Tucson 2015).

The trend is encouraging and shows municipal policies can curb water demand and achieve a better management of the resource. Whether these reductions will prove sufficient in the future is another matter.

A methodological point is important to mention. Southern Nevada and California use very different methods to calculate public water use. The SNWA stresses the difference between withdrawals and return flow (used water collected and returned to Lake Mead, thus available for further use), in effect calculating consumptive use. California does not take into account "recycled water that is delivered within the service area of an urban retail water supplier" that is, recycled water collected and redistributed through urban distribution systems, since the goal is to measure the "water supplied to the distribution system" (CDWR, 2011:14). However, part of the water used in California cities will be collected and reused by other downstream cities, but this is not taken into account since Californian norms do not call for the calculation of consumptive use (which is more complicated to calculate than in Las Vegas because of the local configuration). How much recycled water enters into Californian water distribution is not known; conversely, to what extent would the SNWA approach of returning used water to Lake Mead be considered a recycling given the CDWR protocol remains debatable: the two methods are different and thus figures must be compared with care. In Arizona, figures usually include recycled water and some urban areas provide the share of recycled water in total demand (City of Tucson Water Department 2004).

Authors have underlined efforts to curb water use were all the easier as water demand was high (Hamilton 1983), and critics underline one reason Las Vegas could be so efficient in curbing water demand was that it was so high to begin with (Thompson 2014b). Indeed, it appears efforts to promote a better control of demand are generally easier to implement and reap a better reduction when initial demand is high, because usually this high demand is largely made up of leisure use: watering the yard and garden, cleaning alleys or the car(s), filling the pool, providing air temperature control in outdoor terraces.

\section{Focusing efforts on outdoor water use}

The greater flexibility in leisure water use, concentrated in outdoor water use, encouraged municipal governments to focus on curbing this segment of domestic water demand: it was deemed easier for consumers to give up cleaning the car every week than trying to reduce indoor use (cooking, laundry, toilet use, hygiene...). This focus on outdoor use was also logical for many cities as they often proved to be responsible for a large share of the overall domestic demand: trying to curb outdoor use seemed logical and profitable inasmuch as it was usually considered more flexible and represented a large share of domestic water use. Simulations tend to underline the effectiveness of targeting outdoor use first in the West, since its share in total residential use is large and that it is primarily a leisure use (Qaiser et al. 2011).

Outdoor use is estimated: there is no way to differentiate the meter reading for indoor and outdoor use. Nevertheless, these estimates point to share of outdoor water use in total residential water demand between $40 \%$ (northern California) and 69,5\% in southeastern 
California in 2005 (CDWR 2010); in Albuquerque, outdoor use was estimated at $48 \%$ in 2001; $52 \%$ in Phoenix; $67 \%$ in Tempe (AZ); between $60 \%$ and $70 \%$ in Las Vegas (Western Resource Advocates 2003; Stave 2003).

Californian cities generalized progressive tariff in the early 1990s (Hanak 2007). In the Las Vegas area, systematic metering had an initial impact as it enabled to bill water according to use, and to have the residents know the extent of their own individual use (Lasserre 2011). In Henderson (southern Nevada), per capita use dropped from 437 gpcd in 1954 to 225 gpcd in 1957 after metering was instituted (Morris et al. 1997). Conservation efforts then focused on information/education until 1995, when a program including incentives, water use restriction and a progressive block tariff was instituted (Morris et al. 1997). Public information campaigns, retrofit subsidies and water use restrictions had statistically significant impacts on average monthly residential water use in California, and the more stringent policies had stronger effects than voluntary policies and education programs (Renwick and Green 2000; Olmstead and Stavins 2009; Pacific Institute and NRDC 2014).

\section{An articulate water demand control program}

Las Vegas has managed to cut significantly outdoor water use by incentives to remove lawns in 1999; prohibiting front lawns for new houses since 2003 and encouraging older houses to convert gardens to xeriscaping. The SNWA paid 178 million \$ between 1999 and 2012 to remove 159 million $\mathrm{ft}^{2}$ (14,8 million $\mathrm{m}^{2}$ ) (O'Donoghue 2012). In 2014, the residential water demand control program was articulated around the following points (SNWA 2014b):

\section{Incentives}

- Water Smart Landscapes rebate program: replace grass and thirsty ornamental plants by desert plants and water-efficient landscaping.

- Rebate Coupons/Water Efficient Technologies to encourage the purchase of items that help reduce water use: pool covers to reduce evaporation; rain sensors to cut garden watering when it rains; drip-irrigation systems; low-flow toilets...

\section{Regulation}

- Lawn is prohibited for new houses in front yards since 2003.

- Fountains and mist systems are regulated

- Vehicle washing, landscape watering are restricted and regulated

- Increasing block rates pricing enforced since 1995.

\section{Education}

Maintain information campaigns to inform residents and commercial users of the usefulness of conservation efforts.

As a result, water deliveries from the Southern Nevada Water Authority, which supplies Las Vegas, dropped by 5,26 million $\mathrm{m}^{3}$ from 2002 to 2003 (Walton 2010a), and the model of offering financial incentives to for landscaping changes has inspired several other communities (Hanak 2007).

\section{A focus on outdoor use stemming from water law}

For Las Vegas, this focus on control of outdoor water use was also encouraged by the very structure of the water supply. After the completion of the aqueduct from Lake Mead to Las Vegas in 1971, the city had to fit into the Colorado River water budget that was set through the several interstate agreements that make up what is known as the river law. In 1922, the Colorado River Compact signed by the river basin States (California, Arizona, Nevada forming the lower sub-basin; Wyoming, Utah, Colorado and New Mexico forming the upper subbasin), apportioned the river with equal shares of 7,5 million acre-feet $(\mathrm{Maf})^{1}\left(9,3\right.$ billion $\mathrm{m}^{3}$ ) to each sub-basin. In 1928, the Boulder Canyon Project Act provided for a fixed volume sharing among the lower basin States: Arizona received 2,8 Maf, California 4,4 Maf and Nevada, 0,3 Maf. In 1948, the Upper Colorado River Basin Compact set up a proportional sharing of the upper states' entitlement: Colorado 51,75\%, Utah $23 \%$, Wyoming $14 \%$, New-Mexico 11,25 \% and northern Arizona 0,7 \%. Nevada must therefore limit its water use within 300000 af, but this is a net water budget: Nevada can withdraw larger volumes so long as the net use (withdrawals-return flows) amounts to 300000 af (see Fig. 1).

The Las Vegas area and the SNWA therefore consider the difference between their withdrawals from Lake Mead behind Boulder Dam, and their used water returns, which are accounted for as "return flow credits". Only the difference between withdrawals and return flow credits are accounted for in the 300000 af water budget for Nevada. Given that indoor water use generates waste water that is generally well collected through the sewer system and returned to the Colorado after treatment, there is little incentive for the SNWA and Las Vegas to curb indoor water use (Cooley et al. 2007; SNWA 2014b). This reasoning is criticized by some observers, as return flow credits indeed enable the SNWA to withdraw more water from the Colorado, but in not optimizing the use of this withdrawn water, opportunities are lost: if per capita water use was lower, thanks to an effort on indoor water use being implemented, then a larger population could be serviced with the same volume of withdrawn water. 


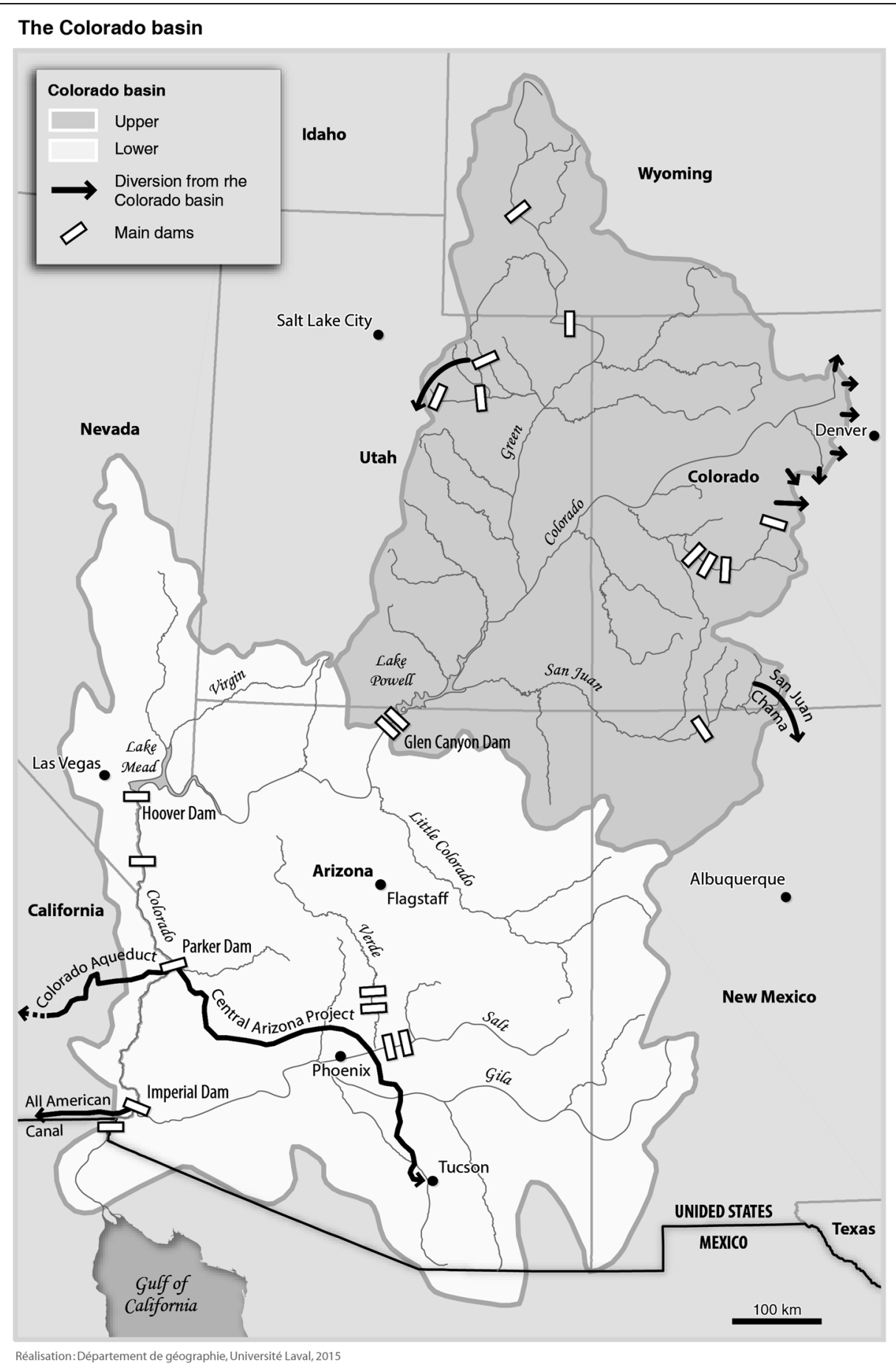

Fig. 1 The Colorado basin. Source: Lasserre 2005

Besides, maintaining a high indoor water use rate makes for larger volumes of water to be withdrawn, treated, pumped in the distribution system, then collected (with leaks accounting for minor, but real losses), treated and pumped back to the Colorado River: these operations cost money for the treatment and the energy needed to pump the water (Cooley et al. 2007).
Observers that compared water demand control programs in Las Vegas and elsewhere in the West noticed there is little incentive to reduce water use indoor (Cooley et al. 2007), a fact the SNWA readily recognizes (SNWA 2004; SNWA 2014b). This return flow credit system explains why the Southern Nevada Water Authority and the Las Vegas Valley Water District place little 
emphasis on indoor water reduction. Indeed, when comparing the water control program in Las Vegas with other Western cities, the difference is quite apparent.

\section{Limits to demand control? Cultural aspects}

True, cultural aspects do affect the responsiveness of citizens to efforts from municipal authorities to encourage water savings. High per capita water demand in the 1930 s up to the 1960 s was partly due to the locally widely held perception that Las Vegas was developing on a vast an inexhaustible aquifer (Morris et al. 1997; Pavelko et al. 1999). Similarly, many residents in Western cities, especially when moving from the Eastern United States, are, on the one hand, not used to adapting their water use to dryer climate conditions and, on the other, nurture a deep-ingrained perception that the perfect home comes along with green grass (Fradkin P 1995; Lasserre 2003; Stave 2003; Hurd 2010), which is poorly adapted to arid climates and therefore requires large amounts of water-no surprise then municipalities often target turf in their water-control policies.

Regarding indoor water use, curbing their use may be all the more difficult as perceptions sometimes prevent citizens from implementing water-saving practices. For instance, water saving incentives through the implementation of low water use standards for taps, double-flush toilets, appliances (dishwasher, clothes washer) have often proved to produce smaller than expected savings because of behavioral changes that partially offset the benefit of greater technical efficiency (Olmstead and Stavins 2009): for instance, people with low-flow showerheads may take longer showers as they think a reduced flow cleans less well.

A research in the Tucson area recently highlighted other cultural barriers to implementing water saving practices. Water used outdoor is associated with pleasure and some consumers are reluctant to moderate their consumption. Similarly, some consumers associate a large volume of water with cleanliness, for toilets or washing machines, and think low-flow toilets or water efficient washing machines do not perform well (Euzen and Morehouse 2014).

\section{Outdoor use and water pricing}

The greater flexibility in leisure water use, concentrated in outdoor water use, explains why pricing definitely has an impact on water use. Most Western cities, and several American cities, like most Western European cities, enforced a progressive block tariff for water use. Not all though: some eastern or central cities have a uniform rate (Memphis, Chicago, New York...) or even a decreasing block rate (Detroit, Milwaukee, Baltimore, Philadelphia...).

The progressive tariff provides that volumes greater than a threshold considered to be dedicated to basic indoor needs (hygiene, cooking and drinking, laundry...) are delivered at a higher price, incenting the consumer to restrain his or her outdoor/leisure use of water (Lasserre 2011), a principle most Western cities have made theirs. This policy garnered positive results as cities often make a strong link between higher tariffs and the decrease of per capita domestic use (Walton 2010a), as was the case with the industry (Lasserre 2011). This trend put an end to the debate on price elasticity regarding water use. Indeed, for long the literature underlined there was no clear reading of price elasticity regarding water use, meaning some studies showed a positive correlation between higher prices and reduced demand, while others stressed this correlation was weak (Young 1973; Williams and Suh 1986; Nieswiadomy 1992; Hamel 2010). Finertuned studies underlined that if price elasticity is limited regarding indoor use-meaning that price does encourage consumers to limit use, its effect is marginal as these uses are more difficult to compress-it is quite high regarding outdoor/leisure use: consumer will pay attention to their bill when it comes to watering lawn and washing their cars (Moncur 1987; Nieswiadomy 1992; Espey et al. 1997; Brookshire et al. 2002; Cooley et al. 2007).

These price measures are causing per capita demand in most cities that enforced progressive pricing to fall, and in some cases plummet (Cooley et al. 2007). Pricing and other measures helped drive demand down in most Western cities. The SNWA recognizes the increasing water rate helped curb water demand in Las Vegas since 1995 (SNWA 2014b). Water use in Tucson, for example, fell $8 \%$ between 2010 and 2013. Households in Fort Worth, Texas, did even better, cutting residential demand by $18 \%$ between 2006 and 2013, and the city expects more savings from new rules adopted in April that permanently restrict lawn-watering to twice per week (Walton 2014).

A closer look at pricing systems questions another western water myth about Western cities charging more per volume to reflect the relative scarcity of water (see Table 2).

It turns out some Western cities charge little when compared to others, like Salt Lake City, Fresno (CA); and that some Eastern cities charge far more than some Western cities, like Philadelphia, New York, Boston or Atlanta: this is because the price is not merely driven by the relative scarcity of water in the region and may reflect the security of supply the city managed to build; and is also the reflection of the water utility, financial situation as well as political choices regarding pricing as a demand management tool.

However, in pinpointing outdoor use as the most effective target of efforts to reduce residential water use, with good arguments, Las Vegas does not seem to mobilize fully the tariff tool. Since it is established that 
Table 2 Average monthly bill (US\$) for a family of four using 50, 100 or 150 gallons/person/day (gpcd), 2014

\begin{tabular}{llll}
\hline & 50 gpcd & 100 gpcd & $150 \mathrm{gpcd}$ \\
\hline Fresno & 19,38 & 28,26 & 37,14 \\
Salt Lake City & 17,22 & 27,19 & 37,79 \\
Milwaukee & 20,81 & 34,65 & 48,49 \\
Chicago & 19,86 & 39,72 & 59,58 \\
Las Vegas & 25,68 & 42,27 & 62,90 \\
Phoenix & 11,55 & 38,75 & 68,45 \\
Dallas & 19,39 & 44,87 & 81,74 \\
New York & 28,64 & 57,28 & 85,92 \\
Philadelphia & 36,14 & 65,83 & 92,76 \\
Tucson & 24,4 & 51,65 & 111,01 \\
Boston & 37,81 & 77,73 & 118,4 \\
Los Angeles & 36,53 & 75,98 & 122,41 \\
Atlanta & 42,64 & 91,92 & 141,2 \\
San Diego & 49,77 & 89,37 & 150,15 \\
Santa Fe & 54,78 & 153,78 & 284,1 \\
\hline
\end{tabular}

Source: Walton 2014 price elasticity is strong when it comes to outdoor water use, several municipalities established an incremental block pricing system, or progressive tariff: the price is low for the first cubic meters that are deemed to be used for indoor, and basic needs; but it gradually increases for subsequent cubic meters that are considered to be mobilized to satisfy leisure needs. The goal of progressive tariff is to send a strong price signal to the consumer: the more you use water, the more expensive the marginal cubic meter becomes. This approach is particularly obvious with cities like Santa Fe, Seattle or Tucson, where prices increase steadily as withdrawals increase (see Fig. 2). However, Las Vegas seems to have a fairly moderate price increase curve, offering the cheapest fare (among the selected cities) for initial volumes, but remaining low-priced volumes even for subsequent cubic meter, whereas targeting outdoor use could have implied adopting a stronger price hike for these volumes.

This reluctance to use the price tool more actively to curb outdoor and even indoor is partly political, but also financially dictated, as explained below. Partly political: water agencies tend to try and keep rates low, in part

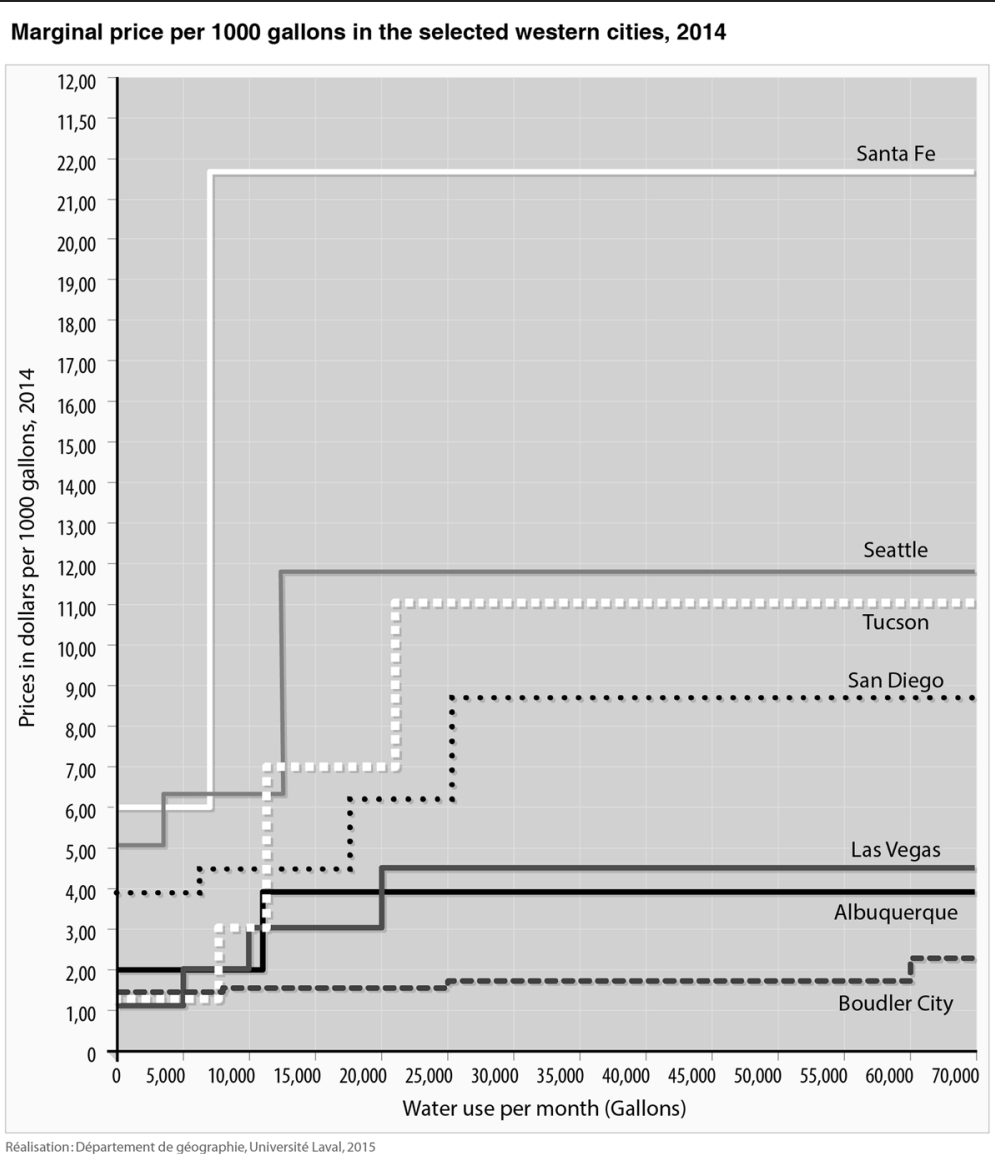

Fig. 2 Marginal price per 1000 gallons in selected Western cities, 2014. Note: For Santa Fe, summer increasing block rates. Source: Water departments of selected cities, data compiled by the author 
because of political pressure from voters. Board members are elected and interact with the municipal government that is also elected. The municipal history of Tucson reflects this, as when, in 1976, the City introduced a progressive block rate structure, every council member who voted for the price increase was voted out of office (Griffin et al. 1991; Walton 2010b).

Pricing remains a difficult tool to use. Incentives like the turf removal program, or regulations on garden watering or car washing can be well-accepted by the population, all the more so if a good communication provides for the understanding of the goals of the measures. But pricing is more delicate as it is sometimes seen as a way to collect hidden taxes (Chicago Tribune 1952; Morris et al. 1997; Blau R 2013).

Moreover, there is a strong financial dimension: water managers are aware they must keep a short-term balance, once a system has been expanded to satisfy large needs, between controlling water demand and securing revenues to finance the water treatment and sewage operations and maintenance. If a price increase is too effective, inducing a strong decrease in demand, then revenues fall, leading to a possible deficit. For many utilities, conservation success expose a financial vulnerability. Because most of their revenue come from water sales, a sudden drop caused the balance sheet to tilt dangerously toward a deficit. Less water sold is less money earned.

Water managers then have two options: increasing further water prices, which sends the wrong signal to consumers who tend to feel they are rewarded for their efforts by higher bills; or increasing fixed water connection fees: Austin, Fort Worth, and Tucson are three examples. This increase in fixed fees means that even those who use water sparingly are paying more (Thompson 2014a, 2014b). This policy also frustrates users and favors a short-term profligate behavior, as it makes average price (monthly service charge + price per volume, divided by used volumes) decline for medium volumes (Cooley et al. 2007), and encourages users to consider careless use of water as a form of recouping their investment in a high fixed fee, as was apparent in interviews with residents from Las Vegas, Phoenix, as well as Montreal and Quebec City (Canada) (Lasserre 2011).

Financial issues, even in the dry West, is a strategic policy determinant, just like water supply or demand control. Water managers have to cope with a structural problem with utility water rates: most costs-such as debt payments-are fixed, but most of the money to pay for them comes from charges on water use, which fluctuates every year. It is not uncommon for a water utility to have a budget with $80 \%$ fixed costs and $20 \%$ that are variable, but, at the same time, to have a revenue stream that is the mirror opposite: $80 \%$ variable (based on water use, which fluctuates and is theoretically pushed down) and $20 \%$ fixed (in the form of standard monthly charges) (Walton 2012). In essence, water utilities make money selling water, and a precarious financial situation leads several to nurture a disincentive to conservation because if customers cut use, it cuts sales (Walton 2010b).

The Southern Nevada Water Authority (SNWA) used to rely on connection fees associated with new homes to provide a significant share of its budget for capital projects. In 2005, near the peak of the region's population and economic expansion, the SNWA approved the construction of a third water-intake pipe into Lake Mead, a project that now costs $\$$ US 800 million (Lasserre 2006). But since then, the housing bubble burst, the national economy went into recession after 2008, and people stopped moving to Las Vegas up until 2014. As a result, revenue from connection charges have fallen dramatically, from \$US 188 million in 2007 to only \$US 3,2 million in 2010 (Walton 2012). Given this collapse, further reducing revenues by developing an aggressive pricing system did not appear very attractive to water managers.

The SNWA and Las Vegas water authorities are facing a serious challenge: water supply remains extremely tight whereas they feel really uncomfortable politically to raise water tariffs, even merely for higher volumes which would target outdoor water use. Besides, this outdoor water use, despite encouraging signs that water demand is being curbed, remains high (Devitt et al. 2010). This sense of emergency as the city felt unable to secure future supplies to satisfy a still growing (if at a slower pace) demand probably triggered the SNWA to turn back to water diversion projects.

\section{Limits to conservation: revert to diversion projects?}

Whereas Las Vegas long relied on groundwater resources up until 1971, then managed to remain within the small Colorado water allocation under the sharing agreements between riparian States, it seems SNWA authorities feel that despite their ongoing efforts, securing the city's water supply cannot be ascertained without water diversions. As of 2009, ideas of long-distance diversions were aired by Patricia Mulroy, director of the SNWA (Las Vegas Review Journal 2009; Las Vegas Review Journal 2011). This represents a return to early $20^{\text {th }}$ century engineering solutions that characterized water management solutions (Lasserre 2005; Gleick 2010) whereas these huge, costly diversion schemes were no longer considered serious options by most water operators or State governments in the 1990s and early 2000s (Lasserre 2005). In a survey conducted in November 2011 with stakeholders and the public on potential solutions to the water supply tension in the Colorado basin, $34 \%$ of the respondents thought 
diversions so as to increase supply were the best solution, with proposals of diversions from the Mississippi, the Missouri, and the Columbia river basins (Bureau of Reclamation 2012; O'Donoghue 2012; Barringer F 2012).
The diversion project that is most dear to the SNWA is the Central Valleys diversion project (Lasserre 2006; Cooley et al. 2007; SNWA 2012; Brean H 2014) (Fig. 3). Considered since 1989 (SNWA 2002), the project is creating a strong controversy as local residents do not

\section{Diversion project from Central Nevada aquifers to Las Vegas}

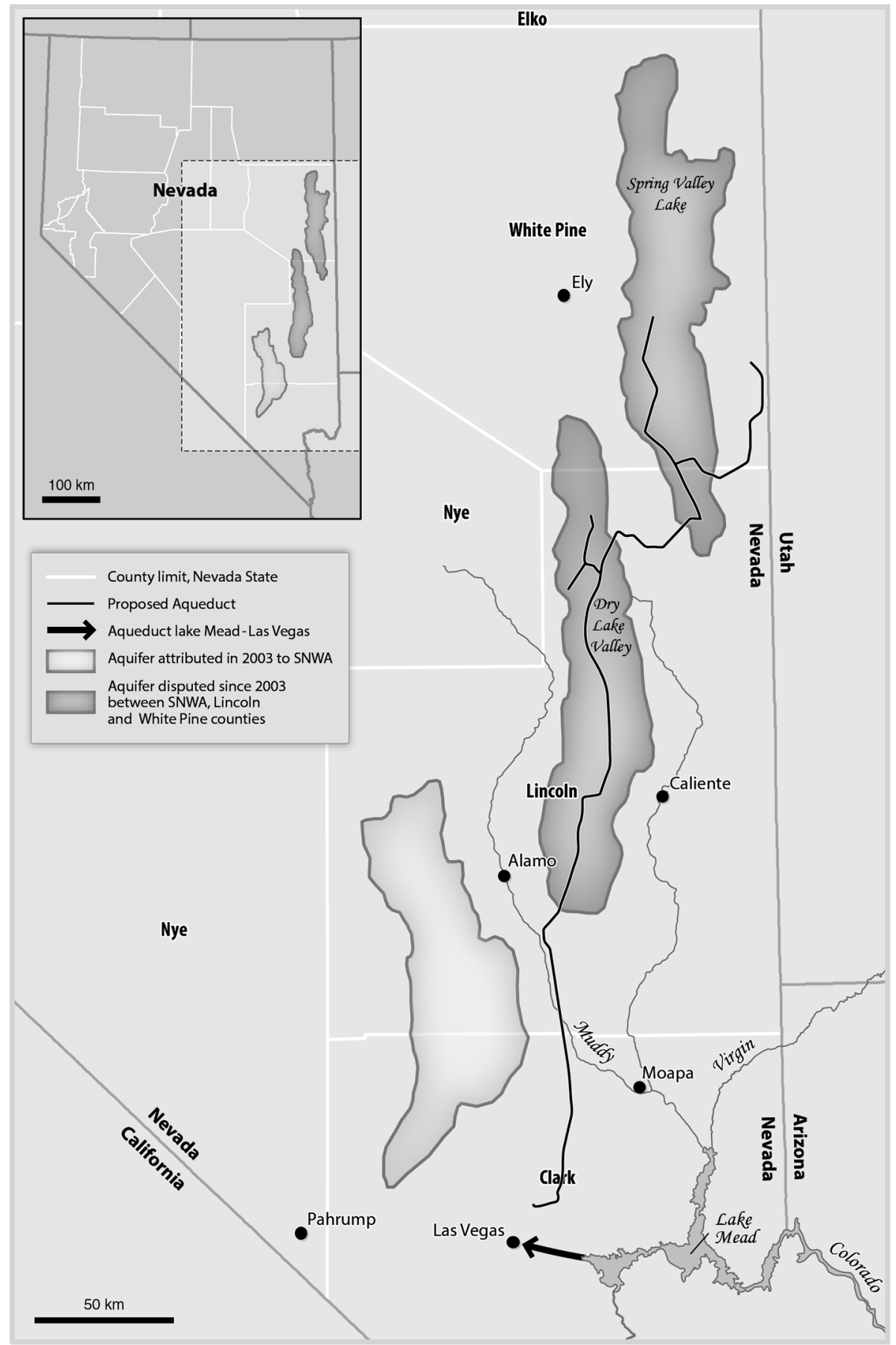

Réalisation: Département de géographie, Université Laval, 2015

Fig. 3 Diversion project from Central Nevada Aquifers to Las Vegas. Source: Lasserre 2006; Lodge R 2012; SNWA 2012 
accept their aquifers potentially being depleted to sustain what they perceive as a profligate and wasteful use of water (Christensen 2000). The legal and political battle proved very costly for the SNWA and may explain why the Authority turned to long-distance water diversion schemes.

\section{Conclusion}

It turns out Las Vegas hotels and casinos are not responsible for the city's large water use: most of it is used by residents. Controlling water use in Las Vegas is tantamount to control residential demand as retail and tourism businesses have implemented efficiency regulations.

Efficiencies remain to be realized in the Southwest in urban and suburban water use. For example, per-capita water use in Tucson is half that in Phoenix despite similarities in climate for the two cities (MacDonald 2010). Las Vegas water authorities did implement water saving measures through price, regulations, education and incentives (SNWA 2011; SNWA 2014b), but critics underline per capita water use remains high (Gleick and Cooley 2011) and pricing appears low when compared to several other Western cities. Political reasons may account for the reluctance of the SNWA to enforce more aggressive tariffs, but financial constraints limit the room for price increase as too steep increases at times produce deficits. Cultural aspects also limit water-effective behaviors. Resorting to long distance water diversions is costly and, as in the case of the Central Valleys, very unpopular with the local population. Managing the water supply dilemma for Las Vegas is thus finding a precarious equilibrium between economic, political, technical imperatives.

\section{Endnote}

${ }^{1}$ One acre-foot is a volume unit equivalent to a surface of one acre covered by a foot-deep of water. It amounts to $1234,4 \mathrm{~m}^{3}$.

\section{Competing interests}

The author declares that he has no competing interest.

Received: 12 March 2015 Accepted: 26 May 2015

Published online: 30 May 2015

\section{References}

Advocates WR (2003) Smart water - a comparative study of urban water use across the southwest. Boulder, $\mathrm{CO}$

Advocates WR (2006) Water in the Urban Southwest. An updated analysis of water use in Albuquerque. Boulder, CO., Las Vegas Valley and Tucson

Balling RJ, Gober P (2007) Climate variability and residential water use in the city of Phoenix, Arizona. Journal of Applied Meteorological Climatology 46:1130-1137

Barringer F (2012) Water Piped to Denver could ease stress on river. New York Times, December 9. Available at www.nytimes.com/2012/12/10/science/ earth/federal-plans-for-colorado-river-include-pipeline.html?_r=1, accessed November 27, 2014
Blau R (2013) City water users are about to get soaked again with another rate hike. New York Daily News, October 21. Available at www.nydailynews.com/ news/politics/city-soak-water-users-article-1.1491150, accessed March 12, 2015

Brean H (2014) Water official: Vegas not running dry. Las Vegas Review Journal, July 15. Available at www.reviewjournal.com/news/water-environment/waterofficial-vegas-not-running-dry, accessed February 12, 2015

Brookshire D, Burness H, Chermak J, Krause K (2002) Western urban water demand. Natural Resources Journal 42:873-898

Bureau of Reclamation (2012) Colorado river basin water supply and demand study. US Department of the Interior, Washington, DC

CDWR (2011) California department of water resources. Methodologies for Calculating Baseline and Compliance Urban Per Capita Water Use. CDWR, Sacramento

CDWR, CDWR, California Department of Water Resources (2010) 20x2020 Water Conservation Plan. CDWR, Sacramento

Chicago Tribune (1952) Free riders on the Water Wagon. October 9. Available at http://archives.chicagotribune.com/1952/10/09/page/20/article/free-riders-onthe-water-wagon, accessed March 12, 2015

Christensen J (2000) Water forces Las Vegas to choose: gaming town or suburb of Los Angeles. In: Miller C (ed) Water in the West. Oregon State University Press, A high Country News Reader. Corvallis, pp 224-232

City of Santa Fe (2014) Water Conservation. Available at www.santafenm.gov/ water_conservation. Accessed March 10, 2015

City of Tucson (2015) About Tucson Water. www.tucsonaz.gov/water/about-us. City of Tucson, AZ. Accessed March 3, 2015

City of Tucson Water Department (2004) Water plan 2000-2050. Department, City of Tucson Water

Cooley H, Hutchins-Cabibi T, Cohen M, Gleick P, Hberger M (2007) Hidden Oasis: water conservation and efficiency in Las Vegas. Pacific Institute and Western Resource Advocates, Oakland

Devitt D and Morris R (2010) Sustainable Water Use in Urban Landscapes in the $21^{\text {st }}$ century: a Las Vegas Perspective. Proceedings of the $2^{\text {nd }}$ Int'l Conference on Landscape and Urban Horticulture, Acta Horticulturae 881

Earl RA, Czerniak RJ (1996) Sunbelt water war: the El Paso-New Mexico water conflict. The Social Science Journal 33(4):359-379

EPWU, El Paso Water Utility (2014) El Paso Water Utilities 2014 Water Conservation Plan. Available at http://www.epwu.org/conservation/pdf/ Conservation_Plan_2014.pdf. Accessed March 10, 2015

Espey M, Espey J, Shaw W (1997) Price elasticity of residential demand for water: a meta-analysis. Water Resources Research 33(6):1369-1374

Euzen A, Morehouse B (2014) De I'abondance à la raison. Norois 231(2):27-41

Fradkin P (1995) The River Revisited. Los Angeles Times Magazine, October 29. Available at http://articles.latimes.com/1995-10-29/magazine/tm-62671_1_ colorado-river-water. Accessed June $16^{\text {th }}, 2013$

Gleick P (2010) Roadmap for sustainable water resources in Southwestern North America. Proceedings of the National Academy of Sciences of the USA 107:21300-21305

Gleick P, Cooley H (2011) Report on water use efficiency and conservation in the Las Vegas Valley. Prepared for the office of the Nevada state engineer. Pacific Institute, Oakland

Griffin A H, Wade J and Martin W (1991) Changes In Water Rates and Water Consumption In Tucson, 1974 to 1978. University of Arizona, Working Paper, http://arizona.openrepository.com/arizona/bitstream/10150/301191/1/ hwr_10-035-039.pdf. Accessed March 6, 2015

Hamel P (2010) Les compteurs d'eau: c'est vraiment trop injuste! Les Cahiers du 27 juin 5(1):27-28

Hamilton LC (1983) Saving water. A causal model of household conservation. Sociological Perspectives 26(4):355-374

Hanak E (2007) Finding water for growth: new sources, new tools, new challenges. Journal of the American Water Resources Association (JAWRA) 43(4):1024-1035

Hurd B (2010) Water-conserving attitudes and Landscape Choices in New Mexico. Choices, the Magazine of Food, Farm and Resources Issues, 25(3), available at www.choicesmagazine.org/magazine/article.php?article=146, accessed March 10,2015

Johnson J (2009) United States water law. Boca Raton, Taylor and Francis \& CRC Press, An Introduction

Las Vegas Review Journal (2009) Mulroy advice for Obama: Tap Mississippi floodwaters. January 12. Available at www.reviewjournal.com/news/mulroyadvice-obama-tap-mississippi-floodwaters. Accessed February 20, 2015

Las Vegas Review Journal (2011) Mississippi may help ease West drought, Mulroy tells chamber. July 20. Available at www.reviewjournal.com/news/water- 
environment/mississippi-may-help-ease-west-drought-mulroy-tells-chamber. Accessed February 20, 2015

Lasserre F (2003) L'eau dans l'Ouest aride des États-Unis. Valeur d'usage, mythes politiques et représentations territoriales d'une société hydraulique. In: Lasserre F, Lechaume A (eds) Le territoire pensé: géographie des représentations territoriales. Presses de I'Université du Québec, Québec, pp 195-212

Lasserre F (2005) Les projets de transferts massifs continentaux en Amérique du Nord. La fin de l'ère des dinosaures? In: Lasserre, Frédéric (dir). Transferts massifs d'eau. Outils de développement ou instrument de pouvoir? Presses de I'Université du Québec, Quebec City, pp 489-534

Lasserre F (2006) La gestion de l'eau dans les agglomérations de l'Ouest américain. Les autorités locales et régionales privilégient toujours une gestion cloisonnée en attendant la crise. In: Brun A, Lasserre F (eds) Les politiques de l'eau. Grands principes et réalités locales. Presses de l'Université du Québec, Québec City, pp 225-251

Lasserre F (2011) L'eau rare? Des solutions pour assurer l'approvisionnement. In: Lasserre F, Descroix L (eds) Eaux et territoires: tensions, coopérations et géopolitique de l'eau, 3rd edn. Presses de I'Université du Québec, Quebec City, pp 69-119

Lasserre F (2012) Gestion de l'eau aux États-Unis. La place du bassin versant dans I'action publique. In: Brun A, Lasserre F (eds) Gestion de l'eau. Approche territoriale et institutionnelle. Presses de I'Université du Québec, Quebec City, pp 45-61

Lodge R (2012) Desert solitaire: Las Vegas bets big on rural water. High Country News, August 15, available at www.hcn.org/blogs/range/desert-solitaire-lasvegas-bets-big-on-rural-water. Accessed March 5, 2015

MacDonald GM (2010) Water, climate change, and sustainability in the Southwest. Proceedings of the National Academy of Sciences 107(50):21256-21262

Moncur J (1987) Urban water pricing and drought management. Water Resources Research 23(3):393-398

Morris R, Devitt D, Crites A, Borden G, Allen L (1997) Urbanization and water conservation in Las Vegas valley, Nevada. Journal of Water Resources Planning and Management 123(3):189-195

Mulroy P (2000) Interview in Captured Rain: American Thirst. Canadian water. Film directed by Jerry Thompson, PBS, New York

Nieswiadomy ML (1992) Estimating urban residential water demand: effects of price structure, conservation, and education. Water Resources Research 28(3):609-615

NOAA - National Oceanic and Atmospheric Administration (2015) NowData - NOAA Online Weather Data. http://w2.weather.gov/climate/xmacis.php?wfo=vef

O'Donoghue A (2012) The fight for water: Can the mighty Mississippi save the West? Deseret News, Salt Lake City, May 13. Available at www.deseretnews.com/ article/865555735/The-fight-for-water-Can-the-mighty-Mississippi-save-theWest.html?pg=all, accessed March 9, 2015

Olmstead SM, Stavins RN (2009) Comparing price and nonprice approaches to urban water conservation. Water Resources Research 45, W04301. doi:10.1029/2008WR007227

Pacific Institute and NRDC (2014) Urban Water Conservation and Efficiency Potential in California. Issue Brief IB:14-05-D. Pacific Institute, Oakland and Natural Resource Defense Council, New York

Pavelko M, Wood D, Laczniak R (1999) Las Vegas, Nevada. Gambling with water in the desert. In: Devin Galloway D, Jones D, Ingebritsen S (eds) Land Subsidence in the United States. Circular 1182. U.S. Geological Survey, Reston VA, pp 49-64

Pitzer G, Eden S, Gelt J (2007) Layperson's Guide to Arizona Water. The University of Arizona, Tucson, AZ, Water Resources Research Center

Qaiser K, Ahmad S, Johnson W, Batista J (2011) Evaluating the impact of water conservation on fate of outdoor water use: a study in an arid region. Journal of Environmental Management 92(8):2061-2068

Renwick ME, Green RD (2000) Do residential water demand side management policies measure up? An analysis of eight California water agencies. Journal of Environmental Economic Management 40(1):37-55

SNWA (2002) 2002 water resource plan. Las Vegas, SNWA

SNWA (2004) Five-year conservation plan: 2004-2009. Las Vegas, SNWA

SNWA (2011) Rebuttal report on water conservation and efficiency in southern Nevada. Presentation to the office of the Nevada State engineer. Las Vegas, SNWA

SNWA (2012) Clark, lincoln, and white pine counties groundwater development project - conceptual plan of development. Las Vegas, SNWA
SNWA (2014a) Water Use Facts - Water Use in Southern Nevada, 2013. Available at www.snwa.com/consv/goals_facts.html. Accessed February 23, 2015

SNWA (2014b) Water conservation plan 2014-2018. Las Vegas, SNWA

SNWA (2015) Drought restrictions and water conservation. Available at www.snwa.com/consv/restrictions.html, Las Vegas, Accessed February 26, 2015

Stave KA (2003) A system dynamics model to facilitate public understanding of water management options in Las Vegas, Nevada. Journal of Environmental Management 67(4):303-313

Thompson S (1999) Water use, management and planning in the United States. Academic, San Diego

Thompson J (2014a) The Vegas Paradox. In Sin City, excess and efficiency walk hand-in-hand. High Country News, 46(1), January 23. Available at https://www.hcn.org/issues/46.1/the-vegas-paradox. Accessed January 15, 2015

Thompson J (2014b) Vegas' new water czar has a tough row to hoe. High Country News, 46(1), January 27. Available at https://www.hcn.org/blogs/ goat/vegass-new-water-czar-has-a-tough-row-to-hoe. Accessed January 15, 2015

USGS, United States Geological Survey (2014a) Summary of estimated water use in the United States in 2010. Fact sheet 2014-3109, November. Department of the Interior, Washington, DC

USGS, United States Geological Survey (2014b) California Water Use, 2010. Available at http://ca.water.usgs.gov/water_use/2010-california-water-use.html. Department of the Interior, Washington, DC. Accessed February 26, 2015

Velotta R (2011) Troubled waters: Las Vegas' perpetual quest to quench itself. Vegas Inc. Magazine, August, available at www.vegasinc.com/business/2011/ aug/01/troubled-waters/, accessed March 2, 2015

Walton B (2010) The Price of Water: A Comparison of Water Rates, Usage in 30 U.S. Cities. Circle of Blue, www.circleofblue.org/waternews/2010/world/theprice-of-water-a-comparison-of-water-rates-usage-in-30-u-s-cities/. Accessed February 16, 2015

Walton B (2010b) U.S. Urban Residents Cut Water Usage; Utilities are Forced to Raise Prices. Circle of Blue, www.circleofblue.org/waternews/2010/world/u-surban-residents-cut-water-usage-utilities-are-forced-to-raise-prices/. Accessed February 16, 2015

Walton B (2012) The Price of Water 2012: 18 Percent Rise Since 2010, 7 Percent Over Last Year in 30 Major U.S. Cities. Circle of Blue, www.circleofblue.org/ waternews/2012/world/the-price-of-water-2012-18-percent-rise-since-2010-7percent-over-last-year-in-30-major-u-s-cities/. Accessed February 16, 2015

Walton B (2014) Price of Water 2014: Up 6 Percent in 30 Major U.S. Cities; 33 Percent Rise Since 2010. Circle of Blue, www.circleofblue.org/waternews/ 2014/world/price-water-2014-6-percent-30-major-u-s-cities-33-percent-risesince-2010/. Accessed February 16, 2015

Williams M, Suh B (1986) The demand for urban water by customer class. Applied Economics 18(12):1275-1289

Young RA (1973) Price elasticity of demand for municipal water: a case study of Tucson, Arizona. Water Resources Research 9(4):1068-1072

\section{Submit your manuscript to a SpringerOpen ${ }^{\circ}$ journal and benefit from:}

- Convenient online submission

- Rigorous peer review

- Immediate publication on acceptance

- Open access: articles freely available online

- High visibility within the field

- Retaining the copyright to your article

Submit your next manuscript at springeropen.com 